\title{
Predicting Fault Locations based on Morphometric Features of Alluvial Fans and Basins using Artificial Neural Networks
}

Marzieh Mokarram ( $\triangle$ m.mokarram@shirazu.ac.ir)

Shiraz University https://orcid.org/0000-0003-4282-1950

Hamid Reza Pourghasemi

Shiraz University

John P. Tiefenbacher

Texas State University

\section{Research Article}

Keywords: Morphometric features, Alluvial fan, Fault, Erosion, Principal component analysis (PCA) method, Adaptive neural-fuzzy network (ANFIS)

Posted Date: June 16th, 2021

DOI: https://doi.org/10.21203/rs.3.rs-607932/v1

License: (c) (i) This work is licensed under a Creative Commons Attribution 4.0 International License. Read Full License 
1 Predicting fault locations based on morphometric features of alluvial fans and basins using artificial neural networks

3

${ }^{1 *}$ Department of Range and Watershed Management, College of Agriculture and Natural

6 Resources of Darab, Shiraz University, Iran, ORCID ID: https://orcid.org/0000-0003-4282-

1950.Email:m.mokarram@shirazu.ac.ir

$8{ }^{2}$ Department of Natural Resources and Environmental Engineering, College of Agriculture,

Shiraz University, Shiraz, Iran, Email: hr.pourghasemi@shirazu.ac.ir

10

${ }^{3}$ Department of Geography, Texas State University, San Marcos, TX USA, Email:

$$
\text { tief@txstate.edu }
$$

12 "Corresponding author: MarziehMokarram, Tel.: +98-917-8020115; Fax: +987153546476 
15 Predicting fault locations based on morphometric features of alluvial fans and basins using artificial neural networks

\section{$17 \quad$ Abstract}

18 The aim of this study is to investigate the morphometry of alluvial fans located in the vicinity of the

19 Sabzevar and Sang-Sefid faults in northeastern Iran to determine their influence on erosion Principal

20 component analysis (PCA) was used to select the most important morphometric factors affecting erosion.

21 The data regarding the important parameters were input into adaptive neural-fuzzy networks (ANFIS) to

22 predict erosion rates. The asymmetric factor (Af), hypsometric integral (Hi), and basin shape (BS) indicate

23 that most of the sub-basins are tectonically active. The results of the PCA revealed that the most important

24 parameters affecting erosion were $A_{\mathrm{f}}, P_{\mathrm{f}}, L_{\mathrm{f}}, \mathrm{R}_{\mathrm{f}}, V_{f}, P_{\mathrm{b}}, A_{\mathrm{b}}, L \mathrm{C}, L_{\mathrm{b}}$, Dd, and the geological unit. The ANFIS

25 method showed that among the soil erosion prediction models, the FCM hybrid model had the highest

26 accuracy. It is concluded that morphometric features can be used to predict the erosion processes in the

27 basin.

29 Keywords: Morphometric features, Alluvial fan, Fault, Erosion, Principal component analysis (PCA)

30 method, Adaptive neural-fuzzy network (ANFIS).

\section{Introduction}

As a river flows out of a mountainous region and enters a plain with a low slope, the capacity for carrying

34 sediment is reduced and an alluvial fan forms (Lancaster et al. 2012) (Fig. S1). Alluvial fans are prominent

35 geomorphological features that form in several climates (Radebaugh et al. 2013). The head of the alluvial

36 fan is located at the site of gradient change, where the stream leaves the mountainous slopes and its base or

37 toe is where the stream exits the fan at its downstream end (Benito 2013).

38 The sediment of alluvial fans includes sand, gravel, silt, and clay, which increase the particle size from

39 upstream to downstream. Deposits near the top or apex of the fan are mostly coarse-grained rock fragments 
and large rubble. Sediments become increasingly fine toward the base, where they are grains of sand, gravel,

41 marl, and clay. Alluvial fans are widespread in arid and semi-arid areas where vegetation is sparse. Some

42 alluvial fans are good sources of aggregates that can be used in construction (Langer et al. 2004).

43 Alluvial fans are affected by an assortment of variables that change from location to location. Alluvial

44 fan processes depend on five factors: lithology, basin shape, conditions in the alluvial fan environment,

45 climate, and tectonic activity (Blair and McPherson 1994). These factors, especially climate and tectonics,

46 affect the inlet and outlet energy (Stokes and Mather 2000; Sancho et al. 2008).

47 These include lithology, basin shape, conditions of the alluvial fan environment, climate, and tectonic

48 activity. These factors, especially climate and tectonics, relate to the inlet and outlet energy. The directions

49 of slopes, the profiles of the channels feeding the alluvial fan, unevenness or relief, flash flood risk, and

50 sediment storage capacity are related to the morphometry of the alluvial fan. Alluvial fans have been found

51 to be useful for studying floods may be studied (Khan et al. 2013). Climate and climate change have

52 significant effects on the morphometry of alluvial fans, because water availability has a direct effect on

53 weathering, sediment production, and vegetation, and climatic conditions control alluvial currents (Harvey

54 et al. 1999).

55 Tectonic activity can induce changes in alluvial fans, particularly affecting their morphometry (Harvey

56 1987). Regardless of the permanence of tectonic activity, alluvial fans are small and short-lived (Parsons,

57 2009). Orographic uplift can generate new sediments that may be deposited on alluvial fans (Beaty 1963).

58 The displacement of the right-slip faults at the alluvial fan formation causes displacement of the alluvial

59 fans and their surface flow. The slope and morphological characteristics of the alluvial fan surface were

60 also somewhat controlled by tectonics. The morphological characteristics of the fans are evidence of

61 tectonic activity (Bull 2007).

62

63 It is very difficult to study alluvial fans in forested areas and deserts. It is also difficult and time 64 consuming to study alluvial fans over large regions (Foster and Beaumont 1992). Using GIS, algorithms, 65 and DEMs, alluvial fans can be more easily observed and analyzed in watersheds and they can be easily 
distinguished from upstream basins (Lagmay et al. 2013). The extraction of geological information from

67 topographic data sets is very important in land studies, but these data can be more easily gathered using a

68 DEM (Fleming et al. 2010). DEMs have been used in studies of volcanoes, faults, slope stability, and

69 landslides. By measuring factors such as elevation and elevation with DEMs, geomorphological features

70 such as cones, volcanoes, fans, and slopes can be analyzed (Eisank et al. 2014). Investigation of the

71 morphometric characteristics of alluvial fans enables the prediction of superficial activities, such as erosion

72 and deposition, as well as internal activities such as tectonics (Roberts and Cunningham 2008).

73 The sedimentary dynamics of alluvial fans are influenced by numerous factors, such as the geology of

74 the upstream lands, which are the sources of sediments, landslides, glaciers, and land use (Chen et al. 2010).

75 Lucà (2012) and Santangelo et al. (2012) investigated the role of morphometry in sedimentation processes.

76 Recent studies have examined the relationships between geology, vegetation, morphometry, and alluvial

77 fan morphometry (Santangelo et al. 2012; Stokes and Gomes 2020; Lucà and Robustelli 2020). GIS

78 techniques and principal component analysis (PCA) (Farhan et al. 2016), logistic regression (LR) (Stokes

79 and Gomes 2020; Lucà and Robustelli 2020), and unsupervised self-organizing maps (SOMs) (Mokarram

80 and Sathyamoorthy 2016) have been merged to investigate the types of alluvial fans and their distinctive

81 morphometries. In recent studies, such as Basu et al. (2020), Ghosh and Gope (2021), and Ilanloo (2011)

82 used fuzzy or ANN approaches to predict the morphometric characteristics of the watershed, and the

83 benefits of both methods were not combined.

84 Therefore, there are watershed characteristics, such as alluvial fans, which are likely to be affected by

85 tectonic and faulting activities where there is active subduction. In contrast, no study has discussed the use

86 of precise methods such as PCA to identify the most important average morphometric features or how these

87 parameters correlate with fault and erosion activities. Hence, in the study area, we combined PCA and

88 artificial neural networks (ANNs) to predict tectonic and erosional activities based on morphometric 89 characteristics.

90 The ANN is a predictive model that has been used in many geomorphological studies but has not yet

91 been applied to the study and prediction of erosion based on alluvial fan morphometry. This study aims to 
92 predict erosion from alluvial fan morphometry using the adaptive network-based fuzzy inference system

93 (ANFIS) method. The alluvial fans in the vicinity of the Sabzevar and Sang-Sefid faults in northeastern

94 Iran are the objects of study. This is among the few articles that have employed the ANN method to

95 investigate and predict alluvial morphometries and their relationships to erosion in upstream watersheds

96 (Lucà and Robustelli 2020). The PCA method was used to determine the most important morphometric

97 parameters affecting the fault activity and soil erosion. This study is also innovative in that it strives to

98 predict fault activity in the region based on the watershed's morphometric characteristics.

99 The remainder of this paper is organized as follows. section 2 explains the case study. In Section 3, the

100 method of extracting alluvial fans is described. In addition, the formulation of the proposed method to select

101 the important morphometric features and the predicted locations of faults based on morphometric features

102 of the alluvial fan using PCA and ANFIS methods in Subsections 3.2 and 3.3. Section 4 describes the

103 morphometric properties of the PCA and ANFIS methods. Finally, Section 5 concludes the paper.

104

105

\section{Geological setting}

107 The study area is located in the Central Desert watershed, located at $35^{\circ} 2{ }^{\prime} 2^{\prime \prime}$ to $35^{\circ} 33^{\prime} 00^{\prime \prime} \mathrm{N}$ and $10857^{\circ} 38^{\prime} 24^{\prime \prime}$ to $59^{\circ} 06^{\prime} 24^{\prime \prime} \mathrm{E}$ (Fig. 1). The study area covers $4,548 \mathrm{~km}^{2}$. The Elevation in the area ranges from 109861 to $2885 \mathrm{~m}$. This region is located in the northern portion of central Iran and is limited to the north by 110 the Alborz Mountains. To the east is the Lut block, and to the west is the Sanandaj-Sirjan zone. Coarse111 grained and fine-grained sediments cover the surface of the plains. The faults in this region are active and 112 are located in the Aladagh-Binalood Mountains (Rajabi et al. 2006).

113 These rocks are composed of ultramafic rocks along the Eurasian subcontinent. The Alpine-Himalayan

114 fold is the last phase of this region. Its morphology is very young and the folds indicate that topography 115 and geological structures have a direct relationship. These sediments folded in a similar way to the pressure 116 regimes in this part of the world. The height of the region is mostly composed of mercenaries and Tirgans. 117 It seems that plate movements have played a crucial role in the folding of sediments because of their 
118 intensity along the southern front, as well as their asymmetry and steepness along the southwestern side. In

119 addition, the movements caused the overlying faults along the landslide to split along the axis of the folds,

120 drift with a slope to the north, and create faults along the foundation rock faults. In the Miocene, folding

121 and drift movements began and monitoring of the strike-slip fault system at the end of the Pliocene led to

122 structural sediment return in this region (Poursoltani et al. 2015). In this region, the primary sediments

123 consist of conglomerate, sandstone, and a large amount of fine-grained sediments. A dark ophiolite

124 boundary and a light gray limestone boundary are distinguishable in this sequence. Climatically, the average

125 annual rainfall at the stations in the basin is $256.5 \pm 35.11 \mathrm{~mm}$. The average annual temperature is $13.99^{\circ} \mathrm{C}$.

126 The absolute maximum temperature of the period of study period was $48^{\circ} \mathrm{C}$ and the absolute minimum was $127-35^{\circ} \mathrm{C}$.

\section{Material and methods}

\section{Extracting the alluvial fans}

131 Studies show that alluvial fans are formed by the accumulation of sediments from the mountain unit 132 (Harvey et al. 2005) which are in the form of conical and their slope is more towards the mountain unit 133 (about 35 degrees (Staley et al. 2006)) (Sanchez-Núñez et al. 2015) (Fig. 2 (a)). The top is the highest point 134 on the fan and the closest location to the mountain unit. The cut channel, which is not always clear, is the 135 alluvial channel that directs the sediment from the top to the downstream areas of the alluvial fan (Blair and 136 McPherson 1994, 2009). Alluvial fans are formed by several transport mechanisms from mountain units. 137 Alluvial fans have different shapes that are influenced by the bedrock, shape of the watershed, climate, and 138 tectonics (Blair and McPherson 2009). The size of a fan is influenced by the size of the watershed; large 139 alluvial fans are formed from large watersheds (Hooke 1968).

140 Alluvial fans were extracted from the study area using a semi-automatic method. A radial profile was 141 prepared for each alluvial fan. Radial profiles are characterized by a conical shape with either a fixed slope 142 or a downward and concave slope with a nearly flat slope downstream (Sánchez-Núñez et al. 2015). The 143 morphometries of an alluvial fan can be a semi-conical surface. In the GIS algorithm, a conical surface is 
144 created by joining a series of profiles radiating from the fan apex. The channels were mapped, the radial 145 slopes were mapped, and the semi-conical surface was interpolated (Fig. 2(b)).

146 Radial profile analysis is mainly based on a fixed or variable minimum slope threshold that examines

147 slope changes along each fan (slope threshold is defined by trial and error or training on a representative 148 alluvial fan). The semi-conical surface of the alluvial fan was used to cut the radial profile. The apex is the 149 location of the input of sediment input to the alluvial fan (Fig. 2(b)). In the next step, the topographic surface 150 was placed on the radial profile to determine the shape of the alluvial fan. Profiles for all of the alluvial fans 151 in the watershed were prepared from the DEM using a stepped process (Fig 3).

152 After extracting the alluvial fans, the morphometric parameters of both the fans and watersheds were 153 determined (Table S1).

154 Asymmetric factor (Af), hypsometric integral index (Hi), and basin shape index (BS) were used to 155 evaluate the effect of faults on watershed morphometry. The aim of this section is to investigate the effect 156 of tectonic activity on the morphometric properties. Each of these indices is described below :

\section{Symmetric Factor $(A f)$}

159 The geometric network of rivers can be described both qualitatively and quantitatively. In areas where 160 the drainage network develops in the presence of tectonic deformation, the drainage network often has a 161 distinct geometric shape and pattern. The asymmetry factor has been linked to describe and understand the 162 relationship between tectonic tilt in watersheds (Fig. S2). The Basin asymmetry was calculated (Eq. 1):

$163 A f=100(A r-A t)$

164 where Ar is the area of the right part of the basin in the downstream direction relative to the main river, 165 and At is the total area of the drainage basin. For the input network that is formed, and when the current is 166 constant in the steady-state, Af $=47.7$. Values above or below 47.7 indicate drainage basin tilt and tectonic 167 activity (Hare and Gardner 1985; Keller and Pinter 2002). 


\section{Hypsometric integral index $(\mathrm{Hi})$}

170 To determine the extent of geological activity, hypsometry was analyzed with Hi. The altimeter curve

171 is the ratio of the total height of the basin to the total area of the basin (Strahler 1952; Keller and Pinter

172 2002). Although this index is not directly related to tectonics, it indirectly shows the distribution of the

173 basin levels. This index was calculated (Eq. 2):

$174 \quad H_{i}=\left(h-H_{\min }\right) /\left(H_{\max }-H_{\min }\right)$

175 where $H_{i}$ is the hypsometric integral index, $H_{\max }$ is the maximum height, $H_{\min }$ is the minimum height, 176 and $h$ is the mean basin height. This index ranges from 0 to 5 for different regions. Higher values indicate 177 a young topography, high elevation, and greater height than the average drainage network. Lower values 178 indicate an equilibrium in the geomorphic processes and reduced tectonic activity.

\section{Basin Shape Index $(B S)$}

181 The shape of each region is directly related to internal and external influences on the watershed. In this 182 regard, it can be concluded that forms are the result of these processes. High values of BS values indicate 183 that tectonic activity occurred in the watershed. Basins with high tectonic activity were more elongated. 184 They become more circular as tectonic activity diminishes during periods of erosion. The BS was calculated 185 (Eq. 3):

$$
B S=B I / B W
$$

BS is the shape of the basin and indicates tectonic activity, BI is watershed length, and BW is watershed width.

\section{PCA method}

191 The most important morphometric parameters were determined by PCA. Thus, using the PCA method, 192 the data (25 morphometric parameters) were reduced and the immaterial parameters were removed and the 193 most important parameters were selected. PCA divides a similarity matrix into a set of axes or orthogonal 
194 (vertical) components. Each axis represents a principal component (PC). The components were weighed 195 and the variance was calculated for each axis, which is a specific value, an eigenvalue (Mellinger 1987;

196 Pezhman et al. 2009). In PCA, the specific values of the similarity matrix are extracted in a stepwise 197 downward trend; the components of the PCA indicate the amount of change they account for in the matrix.

198 Therefore, the first PCA axes accounted for the highest percentage of definable changes. PCA is a variable 199 reduction technique (Dillon and Goldstein 1984).

200 It is relevant to note that by linearly combining the initial variables $\left(X_{1}, X_{2} \ldots X_{n}\right)$, new components will 201 be created. As stated before, by changing the basis of the initial variables in the PCA method, these 202 components prepare different aspects of the primary variables (Manly 1986). Equation 4 depicts the 203 extraction of these components in detail.

$204 \quad Z_{i}=a_{i j} X_{1}+a_{i 2} X_{2}+\ldots+a_{i p} X_{p}$

205 where $Z_{i}$ represents the desired component, $a_{i j}$ is the coefficient of the primary variable, and $X_{i}$ is the 206 primary variable. The coefficients of the initial variables were obtained (Eq. 5):

$$
|R-\lambda I|=0
$$

208 where $I$ is the unit matrix, $\mathrm{R}$ is the correlation matrix between the primary variables, and $\lambda$ is the 209 eigenvalue.

Adaptive Neural Fuzzy Method (ANFIS)

214 This method is based on the first-order Sugeno-fuzzy method. Because the fuzzy system is a very efficient 215 modeling method, it has been widely used. Empirical knowledge is transformed into a mathematical map 216 using linguistic rules. In systems where the knowledge of the expert is either unavailable or inaccurate, the 217 neural network method can be used to create membership functions and rules for the system. For example, 218 the two laws are defined by Eqs. Six and 7 (Bisht and Jangid 2011). 
$220 \quad$ Rule 1: If $\left(x \in A_{1}\right)$ and $\left(x \in B_{1}(\right.$ then $\left.) f_{1}=p_{1} x+q_{1} y+r_{1}\right)$

$221 \quad$ Rule 2: If $\left(x \in A_{2}\right)$ and $\left(x \in B_{2}(\right.$, then $\left.) f_{2}=p_{2} x+q_{2} y+r_{2}\right)$

222

$223 X$ and $y$ are the inputs of the model, $A_{l}$ and $B_{l}$ are fuzzy sets, $f_{l}$ is the output of the model, and $p_{l}, q_{l}$, and $224 r_{l}$ are network design parameters. These rules had a general structure (Fig. S3(a)).

225 Layer 1: All the nodes are adaptive nodes. The output of Layer 1 is the degree of membership of the 226 inputs, which are expressed in (Eqs. 8 and 9):

$$
O_{1, i}=\mu A_{i}(x), \quad \begin{gathered}
227 \\
\text { for } i=1,2 \\
228
\end{gathered}
$$

$$
O_{1, i}=\mu B_{i}(x), \quad \text { for } i=3,4
$$

230 The membership functions is a Gaussian function (Eq. 10):

$$
\mu A(x)=\frac{231}{1+\left|\frac{\left.x z 33_{i}\right|^{2 b_{i}}}{a_{i}}\right|}
$$

234 Layer 2: The output of this layer is the product of the input signals (Eq. 11).

235

$$
O_{2, i}=w_{i}=\mu A_{i}(x) \mu B_{i}(y), \quad \underset{236}{1} 1,2
$$

237 Layer 3: The output of this layer is normalized to that of the previous layer (Eq. 12):

$$
O_{3, i}=\bar{w}_{i}=\frac{w_{i}}{w_{1}+w_{2}}, \quad \begin{gathered}
238 \\
239
\end{gathered}
$$

$240 \quad$ Layer 4: Normalized firing strength from layer 3 (Eq. 13):

$$
O_{4, i}=\bar{w}_{i} f_{i}=\bar{w}_{i}\left(p_{i} x+q_{i} y+r_{i}\right)
$$

243 Layer 5: The output of this layer is the output of the overall system (Eq. 14): 


$$
O_{5, i}=\sum_{i} \bar{w}_{i} f_{i}=\frac{\sum_{i}^{244} w_{i} f_{i}}{\sum_{i}^{4} \aleph_{i}}
$$

where $x$ and $y$ are the crisp inputs, and $A_{i}$ and $B_{i}$ are the language membership functions. $P_{i}, q_{i}$, and $r_{i}$ are

247 the sugar output parameters. The ANFIS also has a structure (Fig. S3 (b)) (Bisht and Jangid, 2011). it is

248 operated in steps (Fig. S4).

249 All statistical calculations were performed using the (Statistical Package for Social Science (SPSS) v.22 250 and Matlab v. 17b.

\section{Results and discussion}

253 In this section, the results for predicting the faults based on the morphometric features of the 254 alluvial fan are provided in subsections 3.1 3.4. To do this, in subsection 3.1, the morphometric 255 properties of each alluvial fan are explained. In addition, in Subsection 3.2. important morphometric 256 parameters for predicting soil erosion using the PCA method were selected. The ANFIS method to predict 257 soil erosion is described in Section 3.3. in Section 3.4, the effect of faults on alluvial morphometry was 258 investigated.

\section{Morphometric properties}

264 1).

265 The mean values for each of the morphometric features of the alluvial fan and its upstream watershed 266 were determined (Table 1). The maximum and minimum $A_{f}$ are 38.63 and $0.75 \mathrm{~km}^{2}$, respectively. The 267 maximum $L_{f}$ is 9.59 and the minimum $L_{f}$ is 1.43 . The minimum alluvial fan elevation was $985 \mathrm{~m}$ and the 268 maximum alluvial fan elevation was $1,392 \mathrm{~m}$. The maximum value of $R_{r f-L}$ was $1,724.93$. The maximum 
slope was $49.5^{\circ}$. The maximum $R_{f}$ is 9 . The maximum angle of the alluvial fan was $86^{\circ}$ and the lowest was $31^{\circ}{ }^{\circ}$. The lowest and highest $B S$ values are 0.82 and 3.9, respectively. The highest value of Cirb was $271 \quad 6.91$.

272 The maximum $V_{f}$ is 11.6. The morphometric characteristics of the recharged watershed of each alluvial 273 fan were also determined. The maximum and minimum fan areas in the basin is 62.52 and $0.46 \mathrm{~km}^{2}$. The 274 maximum and minimum elevations were 2,077 and 1,022 m, respectively. The maximum and minimum $\mathrm{L}_{b}$ 275 values are 11.770 .63 . The maximum and minimum slopes were $86^{\circ}{ }^{\circ}$ and $30^{\circ \circ}$, respectively. The maximum 276 and minimum values of $\mathrm{Mel}$ are 7.9 3.83.

277 The relationship between $A_{f}, V_{f}$, and $A_{b}$ was examined (Fig. 5). There was a significant positive 278 relationship between $A_{f}$ and $V_{f}$ with $A_{b}\left(\mathrm{R}^{2}=0.91\right.$ for $A_{b}$ and $A_{f}$, and $\mathrm{R}^{2}=0.82$ and).

\section{Selecting the important morphometric parameters using PCA}

281 Considering the concentrations of erosion constituents at various monitoring stations, PCA was 282 performed (Fig. 6). The first (40.72\%) and second (18.16\%) PCs together explained approximately 58.88 $283 \%$ of the variance at the stations. The average distribution of weights allocated to the first, second, and third 284 components was also determined for the 54 alluvial fans (Fig. S5).

285 The distribution of the weights of the parameters in each of the first, second and third principal 286 components was graphed (Fig. S5). Parameters $A_{\mathrm{f}}, P_{\mathrm{f}}, L_{\mathrm{f}}, \mathrm{R}_{\mathrm{f}}, V_{f}, P_{\mathrm{b}}, A_{\mathrm{b}}, L \mathrm{C}, L_{\mathrm{b}}, D d$, and formation material 287 had the greatest weights (Table 2). Those that were farthest from the components' lines were the parameters 288 with the greatest influence on erosion.

289 The results of Kaiser-Meyer-Olkin (KMO) and Bartlett's sphericity tests showed that the significance 290 level was $<0.01$, indicating that there were significant relationships among variables in this analysis 291 (Kaiser, 1974. Analysis of variance showed that the parameters that have significant relationships with 292 erosion were $H_{\text {max }} f, \alpha, B S, M e l, C C$, and $D d$. $R_{\mathrm{f}} f, \beta_{\text {min-f }}, R_{f}, C C, L C, R_{r} b, D d$, and formation material were 293 significantly related to lithology (Table 3). The results of Srivastava and Bhattacharya (1998) and Farhan 294 et al. (2017) showed that PCA is suitable for selecting the most morphometric features in a watershed. 


\section{Results of ANFIS}

Grid partitioning, subtractive, and FCM models were used to predict soil erosion using the ANFIS. Hybrid and backpropagation modes were used for each model (run in MATLAB). The results showed that modeling soil erosion in the study area using the subtractive method had the lowest error (Fig. S6 and Table

4). Two radii of 0.01 and 0.03 , were used. The hybrid method with radii of 0.01 and 0.03 had $\mathrm{R}^{2}=0.99$, MSE=0, and RMSE= 0.03, and high accuracy. This method requires four rules (Fig. S7).

The relationships between the parameters $A_{f}, A_{b}, P_{f}, R_{f}, L_{f}$, and soil erosion in the three dimensions are 303 shown (Fig. S8). The results of Gholami et al. (2018) showed that the ANFIS method is an accurate method 304 for predicting parameters in a watershed.

305 In general, several features are found in a fuzzy neural network, such as learning power, as well 306 as costing, classifying, writing, and compiling. Another advantage is that it allows the extraction 307 of fuzzy rules from a variety of information and calculates the basic rules proportionally. Fuzzy 308 neural networks have been proven to have the ability to model multiple processes in recent studies 309 to predict the erosion rate (Nguyen et al. 2020). The artificial neural network (ANN) model 310 performs better when there is sufficient information and data. Observational data are used to train 311 the network, so the system's performance is reduced when there is a lack of data. in the fuzzy 312 inference system, the input and output variables in this model are described linguistically. Because 313 there is no formal method for doing this, the fuzzy system uses innovative approaches when the 314 information is incomplete and contradictory. This is usually time-consuming and error-prone. 315 Nauck and Kruse (1999) used both fuzzy rule generation capability and network training capability 316 in the ANN model, thus overcoming the shortcomings of each and creating the ANFIS method. 317 Some studies have shown that the ANFIS method is extremely accurate in some natural sciences, 318 such as groundwater prediction (Elzain et al. 2021; Seifi et al. 2020), soil (Mehdizadeh et al. 2020), 
predicting erosion (Islam et al. 201; Kaboodvandpour et al. 2015), and water quality (Fu et al.

320 2020), and can provide better results than ANN and fuzzy models.

\section{Results of $A_{f}, H_{i}$, and $B S$}

The effects of faults on alluvial morphometry using $\mathrm{A}_{\mathrm{f}}, \mathrm{H}_{\mathrm{i}}$, and $\mathrm{BS}$ were investigated. The results for

$\mathrm{A}_{\mathrm{f}}$ indicated that watersheds (sub-basins) $11,37,31,29,36,34,39,26,44,21,50,30,28,25,27,18,49$,

$5,24,53$, and 12, with values of $A_{f}<35$ or $A_{f}>65$, are in class 1 . Watersheds $35,23,47,32,41,13,48,6$,

$3,17,20,14$, and 9 , with values $57<\mathrm{A}_{\mathrm{f}}<65$ or $35<\mathrm{A}_{\mathrm{f}}<43$, are in class 2 . And watersheds $45,33,38,46$,

$19,10,16,40,51,2,54,4,52,42,22,15,43,1,7$, and 8 , with $43<\mathrm{A}_{\mathrm{f}}<57$, are in class 3 . According to

the classification by Hamdoni et al. (2008), the sub-basins in class 1 have high tectonic activity (Table 5).

Hi was calculated for the sub-basins using the GIS software. Watersheds 21-34 and 43-54 have the basins and high tectonic activity in these areas (Fig. 8).

The tectonic state of a region can be determined using morphometric features. Bahrami (2013) also concluded that there is a relationship between the morphometric properties of alluvial fans located in Zagros, Iran and the tectonic state. In this study, morphometric features affecting soil erosion were

337 identified using PCA. The parameters $A_{\mathrm{f}}, P_{\mathrm{f}}, L_{\mathrm{f}}, \mathrm{R}_{\mathrm{f}}, V_{f}, P_{\mathrm{b}}, A_{\mathrm{b}}, L \mathrm{C}, L_{\mathrm{b}}, \mathrm{Dd}$, and formation material are the 33825 most useful parameters for predicting erosion (Sharma et al. 2015). As a result, there was a strong 339 correlation between tectonic activity and the morphometric characteristics of alluvial fans in the study area.

340 Therefore, the morphometric characteristics of alluvial fans can be used to determine tectonic activity in an 341 area (Bahrami 2013; Hashemi et al. 2018; Yamani et al. 2012). 


\section{Conclusion}

345 The results show that $A_{\mathrm{f}}, P_{\mathrm{f}}, L_{\mathrm{f}}, \mathrm{R}_{\mathrm{f}}, V_{f}, P_{\mathrm{b}}, A_{\mathrm{b}}, L \mathrm{C}, L_{\mathrm{b}}$, Dd, and formation material had the greatest

346 influence on erosion rates in the study area. PCA was used to identify the most important parameters

347 influencing erosion. Using ANFIS, the soil erosion in the study area was predicted using these parameters.

348 The effects of two large Sabzevar faults and the Sang-e-Sefid fault on the morphometric characteristics of

349 alluvial fans and their watersheds were also investigated. The results showed that tectonic activity was the

350 main factor in the formation, development, and evolution of alluvial fans in the study area. The Sabzevar

351 and Sang-e-Sefid faults have been more influential on morphometry than other tectonic factors. The results

352 show that faults are active in the study area and affect the morphometry of the watershed. One of the most

353 important outcomes of this study is the confirmation of the ability to identify and predict the tectonic

354 activities of the watershed quantitatively. 


\section{Data availability}

356 The data will be available through the corresponding author

\section{Author contributions}

359 Conceptualization by M.M. and H.R.P.; formal analysis by M.M., H.R.P.; initial methodology and 360 investigation by M.M., H.R.P.J.P.T.; project administration by J.P.T., supervision by H.R.P., and M.M.;

361 validation by J.P.T., H.R.P. and M.M.; visualization and software by M.M.; writing—original draft by and

362 M.M. and H.R.P.; writing-by J.P.T.

363

364 Competing interests

365 The authors declare that they have no conflict of interest.

366

367 Special issue statement

368 Not.

369

370 Acknowledgements

371 The authors would like to thank Shiraz University for providing financial support (grant number: 289432-

372 209) for this study.

\section{Financial support}

374 This research is supported by Shiraz University. 


\section{References}

Bahrami S (2013) Tectonic controls on the morphometry of alluvial fans around

379

380

Danehkhoshk anticline, Zagros, Iran. Geomorphology (180: 217-230.

Beaty CB (1963) Origin of Alluvial Fans, White Mountains, California and Nevada, Ann.

Am. Assoc. Geogr Vol. 53: PP. 516-535.

Benito G (2013) Hazardous processes: flooding. In: Shroder, J. (Ed.), Treatise on

geomorphology. Geomorphology of Human Disturbances, Climate Change, and, Natural

Hazards. Academic Press, San Diego, CA 243-261.

Bisht DCS, Jangid A (2011) Discharge modelling using adaptive neuro-fuzzy inference

system. Int. J. Adv. Sci. Technol, 31 (2011), 99-114

Blair T, McPherson J (1994) Alluvial fan processes and forms. In: Parsons, A.J, Abrahams,

A.D. (Eds.), Geomorphology of Desert Environments. Chapman \& Hall, London, 354-402.

Blair TC, McPherson JG (2009) Processes and forms of alluvial fans. In: Parsons, A.J,

Abrahams, A.D. (Eds.), Geomorphology of Desert Environments, second ed. Springer, Berlin, 413-467.

\section{Bull WB (2007 Tectonic Geomorphology of Mountains , A New Approach to}

Paleosiesmology, Blackwell, 316.

Chen CH, Wang CH, Hsu YJ, Yu SB, Kuo LC (2010) Correlation between groundwater level and altitude variations in land subsidence area of the Choshuichi Alluvial Fan, Taiwan. Eng. Geo 115(2): 122-131

Dillon WR, Goldstein R (1984) Multivariate Analysis Methods and Application. John Wiley and Sons. $453 \mathrm{pp}$

Eisank C, Smith M, Hillier J (2014) Assessment of multiresolution segmentation for delimiting drumlins in digital elevation models. Geomorphology, 214: 452-464. 
Farhan Y, Anbar A, Al-Shaikh N, Mousa R (2016) Prioritization of semi-arid agricultural 402 watershed using morphometric and principal component analysis, remote sensing, and GIS 403 techniques, the Zerqa River Watershed, Northern Jordan Agric Sci 8(1): 113-148

404 Farhan Y, Anbar A, Al-Shaikh N, Mousa R (2016) Prioritization of semi-arid agricultural 405 watershed using morphometric and principal component analysis, remote sensing, and GIS 406 techniques, the Zerqa River Watershed, Northern Jordan. Agric. Sci. 8(1): 113-148

407 Fleming C, Marsh SH, Giles JRA (2010) Introducing elevation models for geoscience. In:

408 Fleming, C, Marsh, S.H, Giles, J.R.A. (Eds.), Elevation Models for Geoscience. Geological 409 Society, London, Special Publication 345: 1-4.

410 Foster NH, Beaumont EA (1992) Photogeology and photogeomorphology. American 411 Association of Petroleum Geologists, Tulsa, OK, USA.

412 Gholami A, Bonakdari H, Ebtehaj I, Gharabaghi B, Khodashenas SR, Talesh SHA, Jamali A 413 (2018) A methodological approach of predicting threshold channel bank profile by multi414 objective evolutionary optimization of ANFIS. Eng Geo 239: 298-309

415 Hamdouni RE, Irigaray C, Fernandez T, Chacon J, Keller EA (2008) Assessment of relative 416 active tectonic, south west border of the sierra novada. (Southern Spain). Geomorphology 96: 417 150- 173.

418 Hare PW, Gardner TW (1985) Geomorphic indicators of vertical neotectonism along 419 converging plate margins, Nicoya Peninsula, Costa Rica. In: Morisawa M, Hack JT (Eds.) 420 Tectonic Geomorphology. Proceedings of the 15th Annual Binghamton Geomorphology 421 Symposium. Allen and Unwin, Boston,123-134.

422 Harvey A, Mather AE, Stokes M (2005) Alluvial fans: geomorphology, sedimentology, 423 dynamics-introduction, a review of alluvial fan research. In: Harvey, A, Mather, A.E, Stokes, M. 
424 (Eds.), Alluvial fans: geomorphology, sedimentology, dynamics. Geological Society Special 425 Publication 251, London, 1-8.

426 Harvey AM, Wells SG (1987) Response of Quaternary fluvial systems to differential 427 epeirogenic uplift: Aguas and Feos river systems, southeast Spain. Geo 15(8): 689-693

428 Harvey AM, Wigand PE, Wells SG (1999) Response of alluvial fan systems to the late

429 Pleistocene to Holocene climatic transition: contrasts between the margins of pluvial Lakes

430 Lahontan and Mojave, Nevada and California, USA. Catena, 36(4): 255-281

431 Hooke RL (1968) Model geology: prototype and laboratory streams: discussion. Geol. Soc.

432 Am. Bull. 79: 391-394

433 Jang JS (1993) ANFIS: adaptive-network-based fuzzy inference system. IEEE transactions on 434 systems, man, and cybernetics 23(3): 665-685

435 Kaiser H (1974) An index of factorial simplicity. Psychometrika, 39: 31-6.

436 Keller EA, Pinter N (2002) Active Tectonics: Earthquakes, Uplift, and Landscape (2nd Ed.).

437 Prentice Hall, New Jersey

438 Khan MA, Haneef M, Khan AS, Tahirkheli T (2013) Debris-flow hazards on tributary

439 junction fans, Chitral, Hindu Kush Range, northern Pakistan. J Asian Earth Sci 62: 720-733.

440 Lagmay AMF, Eco RN, Alconis J, Salvio B (2013) What hit Barangay Andap, New Bataan,

441 Compostela Valley (initial assessment). Project NOAH Open-File Report, Manila, Philippines.

442 Lancaster J, Spittler T, Short W (2012) Using digital geologic maps to assess alluvial-fan

443 flood hazards. In: Soller, D.R. (Ed.), Digital Mapping Techniques Workshop Proceedings. U.S.

444 Geological Survey Open-File Report 1171, Washington, USA, 53-64.

445 Langer WH, Drew LJ, Sachs JS (2004) Aggregate and the environment: American

446 Geological Institute Environmental Awareness, Series 8: 64. 
Lucà F (2012) Valutazione di pericolosità geomorfologiche indotte da fenomeni naturali

448 tramite l'applicazione di modelli statistico- matematici. (PhD dissertation) University of

449 Calabria Rende (CS) Italy 204 pp.

450 Lucà F, Robustelli G (2020) Comparison of logistic regression and neural network models in 451 assessing geomorphic control on alluvial fan depositional processes (Calabria, southern Italy).

452 Environ Earth Sci 79(1): 1-18

453 Manly BF (1986) Multivariate Statistical Methods: A Primer. London, UK: Chapman and 454 Hall.

455 Mellinger M (1987) Multivariate data analysis: its methods. Chemometrics and Intelligent 456 Laboratory Systems 2: 29-36.

457 Mokarram M, Sathyamoorthy D (2016) Clustering of landforms using self-organizing maps 458 (SOM) in the west of Fars province. In IOP Conf. Series: Earth Environ Sci 37: 012009.

459 Parsons T (2009) Lasting earthquake legacy. Nature, 462(7269): 42-43

460 Pezhman HA, Nabi Bidhendi GH, Karbasi AR, Mehrdadi N, Bidhendi ME (2009) Evaluation

461 of spatial and seasonal variations in surface water quality using multivariate statistical

462 techniques, Int J Environ Sci Technol 6: 467-476

463 Radebaugh J, Lorenz RD, Farr TG, Kirk RL, Lunine JI, Ventra, D Le Gall A, Lopes RMC,

464 Barnes JW, Hayes A, Stofan ER, Wall SD, Wood C (2013) Alluvial fans on Titan reveal

465 materials, processes and regional conditions. 44th Lunar and Planetary Science Conference, The

466 Woodlands, Texas, USA, 2641.

467 Roberts N, Cunningham D (2008) Automated alluvial fan discrimination, Quaternary fault

468 identification, and the distribution of tectonically reactivated crust in the Gobi Altai region,

469 southern Mongolia. Int. J. Remote Sens 29(23): 6957-6969 
471 Hernández JR (2015) Geomorphology, internal structure and evolution of alluvial fans at

472 Motozintla, Chiapas, Mexico. Geomorphology 230 (1-12.

473 Santangelo N, Daunis-i Estadella J, Di Crescenzo G, Di Donato V, Faillace PI, Martín-

474 Fernández JA, Romano P, Santo A, Scorpio V (2012) Topographic predictors of susceptibility to 475 alluvial fan fooding Southern Apennines. Earth Surf Process. 37:803-817

476 Sharma SK, Gajbhiye S, Tignath S (2015) Application of principal component analysis in 477 grouping geomorphic parameters of a watershed for hydrological modeling. Appl Water Sci $478 \quad 5(1): 89-96$

479 Srivastava HN, Bhattacharya SN (1998) Application of principal component analysis to some 480 earthquake related data in the Koyna region, India Engin Geo 50(1-2): 141-151

481 Staley DM, Wasklewicz TA, Blaszczynki JS (2006) Surficial patterns of debris flow 482 deposition on alluvial fans in Death Valley, CA using airborne laser swath mapping data. 483 Geomorphology 74: 152-163

484 Stokes M, Gomes A (2020) Alluvial fans on volcanic islands: A morphometric perspective 485 (São Vicente, Cape Verde). Geomorphology 368: 107356

486 Strahler AN (1952) Hypsometric (area-altitude) analysis of erosional topography. Geol Soc 487 Am Bull 63(11): 1117-1142

488 Sancho C, Peña, JL, Rivelli F, Rhodes E, Muñoz A (2008) Geomorphological evolution of the 489 Tilcara alluvial fan (Jujuy Province, NW Argentina): Tectonic implications and 490 palaeoenvironmental considerations. J S Am Earth Sci 26(1), 68-77

491 Stokes M, Mather AE (2000) Response of Plio-Pleistocene alluvial systems to tectonically 492 induced base-level changes, Vera Basin, SE Spain. J Geol Soc 157(2), 303-316 
493 Nauck, D, Kruse, R, (1999), Obtaining Interpretable fuzzy Classification Rules from Medical

494 Data, Artif Intell Med 16 (2), PP (149-169

495 Seifi A, Ehteram M, Singh VP, Mosavi A (2020) Modeling and uncertainty analysis of 496 groundwater level using six evolutionary optimization algorithms hybridized with ANFIS, SVM, 497 and ANN. Sustainability 12(10), 4023

498 Elzain HE, Chung SY, Park KH, Senapathi V, Sekar S, Sabarathinam C, Hassan M (2021)

499 ANFIS-MOA models for the assessment of groundwater contamination vulnerability in a nitrate 500 contaminated area. J Environ Manage 286, 112162

501 Fu Z, Cheng J, Yang M, Batista J, Jiang Y (2020) Wastewater discharge quality prediction using 502 stratified sampling and wavelet de-noising ANFIS model. Comput Electr Eng 85, 106701

503 Mehdizadeh S, Ahmadi F, Kozekalani Sales A (2020) Modelling daily soil temperature at 504 different depths via the classical and hybrid models. Meteorol. Appl 27(4), 1941

505 Nguyen KA, Chen W, Lin BS, Seeboonruang U (2020). Using Machine Learning-Based 506 Algorithms to Analyze Erosion Rates of a Watershed in Northern Taiwan. Sustainability 12(5), $507 \quad 2022$

508 Kaboodvandpour S, Amanollahi J, Qhavami S, Mohammadi B (2015) Assessing the accuracy of 509 multiple regressions, ANFIS, and ANN models in predicting dust storm occurrences in Sanandaj, 510 Iran. Nat Hazards 78(2), 879-893

511 Islam MR, Jaafar WZW, Hin LS, Osman N, Hossain A, Mohd NS (2018) Development of an 512 intelligent system based on ANFIS model for predicting soil erosion. Environ Earth Sci 77(5), 1$513 \quad 15$ 
514 Poursoltani MR, Jamali M, Nasiri Y (2015) Lithofacies, Petrofacies and depositional

515 environment of Jurassic deposits in Binalood Zone in the Bazeh hoz section, South of

516 Mashhad. Applied Sedimentology 3(6), 82-102

517 Ilanloo M (2011) A comparative study of fuzzy logic approach for landslide susceptibility

518 mapping using GIS: An experience of Karaj dam basin in Iran. Procedia Soc Behav Sci 19, 668-

519676

520 Ghosh M, Gope D (2021) Hydro-morphometric characterization and prioritization of sub-

521 watersheds for land and water resource management using fuzzy analytical hierarchical process

522 (FAHP): a case study of upper Rihand watershed of Chhattisgarh State, India. Appl Water Sci

$52311(2), 1-20$

524 Basu T, Das A, Pal, S (2020) Application of geographically weighted principal component

525 analysis and fuzzy approach for unsupervised landslide susceptibility mapping on Gish River

526 Basin, India. Geocarto Int 1-24

527 Hashemi F, Derakhshani R, Bafti SS, Raoof A (2018) Morphometric dataset of the alluvial fans 528 at the southern part of Nayband fault, Iran. Data brief 21, 1756-1763

529 Bahrami S (2013) Tectonic controls on the morphometry of alluvial fans around Danehkhoshk

530 anticline, Zagros, Iran. Geomorphology 180, 217-230

531 Yamani M, Maghsoudi M, Ghassemi MR, Mohammadnejad V (2012) Morphologic and

532 Morphometric Evidence for Active Tectonic Effects on Alluvial Fans in North Damghan. Phys

533 Geog Res 44(2), 1-18 
Table 1. Morphometric features of alluvial fans in the study area

\begin{tabular}{|c|c|c|c|c|}
\hline Parameters & Minimum & Maximum & Average & STDVI \\
\hline$A_{\mathrm{f}}$ & 0.75 & 38.63 & 6.62 & 7.68 \\
\hline$P_{\mathrm{f}}$ & 3.57 & 26.84 & 9.88 & 5.6 \\
\hline$L_{\mathrm{f}}$ & 1.43 & 9.59 & 3.85 & 2.2 \\
\hline$H_{\min \_f} f$ & 985 & 10990 & 1292.19 & 1348.05 \\
\hline$H_{\max \_} f$ & 1036 & 1392 & 1217.39 & 100.91 \\
\hline$\Delta H_{\mathrm{f}}$ & 1010.5 & 6054.5 & 1254.79 & 672.1 \\
\hline$R_{\mathrm{r}} f \_\mathrm{L}$ & 120.8 & 1724.93 & 418.59 & 263.81 \\
\hline$\beta_{\mathrm{f}}$ & 5.35 & 49.5 & 29.73 & 8.28 \\
\hline $\mathrm{R}_{\mathrm{f}}$ & 0.49 & 9 & 2.19 & 1.42 \\
\hline Erosion & 3 & 7 & 6.07 & 1.03 \\
\hline$\alpha$ & 31 & 86 & 62.31 & 12.54 \\
\hline BS & 0.82 & 3.9 & 1.92 & 0.62 \\
\hline Cirb & 0.64 & 6.91 & 2.44 & 1.66 \\
\hline$V_{f}$ & 0.11 & 11.6 & 1.89 & 2.41 \\
\hline$P_{\mathrm{b}}$ & 2.74 & 33.66 & 11.93 & 7.31 \\
\hline$A_{\mathrm{b}}$ & 0.46 & 62.52 & 11.75 & 13.91 \\
\hline$H_{\text {min } \_} b$ & 1022 & 1411 & 1216.31 & 112.65 \\
\hline$H_{\max \_} b$ & 1049 & 2077 & 1542.59 & 307.47 \\
\hline$\Delta H_{\mathrm{b} / \mathrm{L}}$ & 4 & 813 & 326.28 & 232.46 \\
\hline$L_{\mathrm{c}}$ & 0.63 & 11.77 & 3.68 & 2.7 \\
\hline$L_{\mathrm{b}}$ & 1.03 & 13.56 & 4.64 & 3.02 \\
\hline$\Delta \mathrm{Hb}$ & 0.88 & 247.02 & 81.03 & 54.37 \\
\hline$\beta_{\mathrm{b}}$ & 30 & 86 & 72.37 & 12.08 \\
\hline$D_{\mathrm{d}}$ & 141.5 & 1135 & 759.1 & 257.82 \\
\hline $\mathrm{Mel}$ & 3.83 & 7.9 & 13.79 & 7.82 \\
\hline
\end{tabular}

Table 2. Special vector of each parameters using the PCA method

\begin{tabular}{cccccccc}
\hline \multirow{2}{*}{ Code } & \multirow{2}{*}{ Parameters } & \multicolumn{6}{c}{ Component } \\
\cline { 3 - 8 } & $\mathbf{1}$ & $\mathbf{2}$ & $\mathbf{3}$ & $\mathbf{4}$ & $\mathbf{5}$ & $\mathbf{6}$ \\
\hline $\mathrm{A}$ & $A_{\mathrm{f}}$ & .928 & -.048 & .030 & -.116 & .169 & .044 \\
$\mathrm{~B}$ & $P_{\mathrm{f}}$ & .969 & -.041 & .089 & -.101 & .053 & .064 \\
$\mathrm{C}$ & $L_{\mathrm{f}}$ & .941 & .001 & .225 & -.075 & -.040 & .047 \\
$\mathrm{D}$ & $H_{\min \_} f$ & -.090 & -.210 & .242 & .794 & .261 & .315 \\
$\mathrm{E}$ & $H_{\max \_} f$ & .143 & .726 & .222 & .271 & -.108 & -.461 \\
$\mathrm{~F}$ & $R_{\mathrm{r} f}$ & -.629 & -.038 & .105 & .656 & .281 & .105 \\
$\mathrm{G}$ & $\beta_{\min -\mathrm{f}}$ & -.305 & .690 & -.193 & .060 & -.131 & -.045 \\
$\mathrm{H}$ & $\beta_{\max -\mathrm{f}}$ & .094 & .075 & -.095 & .172 & -.492 & -.129 \\
$\mathrm{I}$ & $\mathrm{R}_{\mathrm{f}}$ & .838 & -.078 & -.234 & -.129 & .355 & .092 \\
$\mathrm{~J}$ & $\alpha$ & -.232 & .186 & .594 & -.293 & .414 & -.237 \\
$\mathrm{~K}$ & $\mathrm{BS}$ & -.029 & -.061 & .737 & -.089 & -.404 & .125 \\
$\mathrm{~L}$ & $V_{f}$ & .878 & .024 & .099 & -.168 & .314 & .007 \\
$\mathrm{M}$ & $P_{\mathrm{b}}$ & .965 & -.044 & .040 & .128 & -.046 & -.041 \\
$\mathrm{~N}$ & $A_{\mathrm{b}}$ & .935 & -.048 & .081 & .030 & .004 & -.054 \\
$\mathrm{O}$ & $H_{\min \_} b$ & .172 & .812 & .272 & .219 & .076 & -.375 \\
$\mathrm{P}$ & $H_{\max \_} b$ & .537 & .813 & .020 & .059 & .062 & .053 \\
$\mathrm{Q}$ & $M e l$ & -.461 & -.006 & .545 & -.372 & -.003 & .244 \\
$\mathrm{R}$ & $\mathrm{CC}$ & .012 & -.056 & -.699 & -.141 & .113 & -.233 \\
$\mathrm{~S}$ & $L \mathrm{C}$ & .930 & -.096 & .125 & .113 & -.023 & -.034 \\
$\mathrm{~T}$ & $L_{\mathrm{b}}$ & .935 & -.077 & .138 & .150 & -.059 & -.016 \\
$\mathrm{U}$ & $R_{\mathrm{r}} b$ & -.166 & .823 & -.262 & -.120 & .036 & .284 \\
$\mathrm{~V}$ & $\beta_{\min -\mathrm{b}}$ & .150 & .781 & -.113 & -.005 & -.166 & .417 \\
$\mathrm{~W}$ & $\beta_{\max -\mathrm{b}}$ & .249 & .856 & -.035 & -.088 & .096 & .252 \\
$\mathrm{X}$ & $\mathrm{Dd}$ & .815 & -.147 & -.248 & .284 & -.059 & .013 \\
$\mathrm{Y}$ & $\mathrm{Geology}$ & .767 & -.230 & -.030 & .056 & -.411 & .099 \\
\hline & unit & & & & & & \\
\hline
\end{tabular}


Table 3. Analysis of variance of parameter values

\begin{tabular}{|c|c|c|c|c|c|c|c|c|c|c|c|}
\hline \multicolumn{7}{|c|}{ Erosion } & \multicolumn{5}{|c|}{ Lithology } \\
\hline Code & Parameters & $\begin{array}{c}\text { Sum of } \\
\text { Squares }\end{array}$ & df & $\begin{array}{c}\text { Mean } \\
\text { Square }\end{array}$ & $\mathbf{F}$ & Sig. & $\begin{array}{c}\text { Sum of } \\
\text { Squares }\end{array}$ & df & $\begin{array}{c}\text { Mean } \\
\text { Square }\end{array}$ & $\mathbf{F}$ & Sig. \\
\hline A & $\overline{A_{\mathrm{f}}}$ & 110.666 & 3 & 36.889 & .612 & .610 & 275.688 & 5 & 55.138 & .930 & .470 \\
\hline B & $P_{\mathrm{f}}$ & 86.282 & 3 & 28.761 & .914 & .441 & 149.084 & 5 & 29.817 & .948 & .459 \\
\hline $\mathrm{C}$ & $L_{\mathrm{f}}$ & 19.884 & 3 & 6.628 & 1.406 & .252 & 20.742 & 5 & 4.148 & .848 & .523 \\
\hline D & $H_{\min } f$ & 1898599.934 & 3 & 632866.645 & .335 & .800 & 5.329 & 1 & 5.329 & 1.089 & .302 \\
\hline E & $H_{\max } f$ & 113876.637 & 3 & 37958.879 & 4.458 & .008 & 6.919 & 1 & 6.919 & 1.414 & .240 \\
\hline $\mathrm{F}$ & $R_{\mathrm{r}} f$ & 220379.409 & 3 & 73459.803 & 1.059 & .375 & 22166497.023 & 5 & 4433299.405 & 2.870 & .024 \\
\hline G & $\beta_{\text {min-f }}$ & 226.071 & 3 & 75.357 & .920 & .438 & 219793.633 & 5 & 43958.727 & 6.597 & .000 \\
\hline $\mathrm{H}$ & $\beta_{\text {max-f }}$ & 120.235 & 3 & 40.078 & .217 & .884 & 466141.586 & 5 & 93228.317 & 1.389 & .245 \\
\hline I & $\mathrm{R}_{\mathrm{f}}$ & 3.185 & 3 & 1.062 & .509 & .678 & 2616.331 & 5 & 523.266 & 14.741 & .000 \\
\hline $\mathrm{J}$ & $\alpha$ & 1849.880 & 3 & 616.627 & 4.757 & .005 & 808.241 & 5 & 161.648 & .909 & .483 \\
\hline $\mathrm{K}$ & BS & 4.039 & 3 & 1.346 & 4.086 & .011 & 9.926 & 5 & 1.985 & .976 & .442 \\
\hline $\mathrm{L}$ & $V_{f}$ & 19.254 & 3 & 6.418 & 1.111 & .353 & 1378.765 & 5 & 275.753 & 1.904 & .111 \\
\hline $\mathrm{M}$ & $P_{\mathrm{b}}$ & 213.538 & 3 & 71.179 & 1.358 & .266 & 1.270 & 5 & .254 & .634 & .675 \\
\hline $\mathrm{N}$ & $A_{\mathrm{b}}$ & 621.650 & 3 & 207.217 & 1.076 & .368 & 31.870 & 5 & 6.374 & 1.108 & .369 \\
\hline $\mathrm{O}$ & $H_{\min \_} b$ & 72939.452 & 3 & 24313.151 & 2.027 & .122 & 5.216 & 1 & 5.216 & .906 & .346 \\
\hline $\mathrm{P}$ & $H_{\max } b$ & 340177.989 & 3 & 113392.663 & 1.214 & .314 & 150.057 & 5 & 30.011 & .536 & .748 \\
\hline $\mathrm{Q}$ & $\mathrm{Mel}$ & 83709.498 & 3 & 27903.166 & 3.289 & .028 & 771.637 & 5 & 154.327 & .782 & .568 \\
\hline $\mathrm{R}$ & $\mathrm{CC}$ & .094 & 3 & .031 & 2.370 & .082 & 256793.148 & 5 & 51358.630 & 5.930 & .000 \\
\hline $\mathrm{S}$ & $L \mathrm{C}$ & 17.433 & 3 & 5.811 & .785 & .508 & 1140675.212 & 5 & 228135.042 & 2.830 & .026 \\
\hline $\mathrm{T}$ & $L_{\mathrm{b}}$ & 33.181 & 3 & 11.060 & 1.228 & .309 & 46815.179 & 5 & 9363.036 & .975 & .443 \\
\hline U & $R_{\mathrm{r}} b$ & 16768.019 & 3 & 5589.340 & 1.997 & .126 & .162 & 5 & .032 & 2.604 & .037 \\
\hline $\mathrm{V}$ & $\beta_{\text {min-b }}$ & 293.478 & 3 & 97.826 & .594 & .622 & 25.736 & 5 & 5.147 & .683 & .638 \\
\hline W & $\beta_{\text {max-b }}$ & 498.113 & 3 & 166.038 & .606 & .614 & 35.014 & 5 & 7.003 & .749 & .591 \\
\hline $\mathrm{X}$ & Dd & 487089.803 & 3 & 162363.268 & 2.674 & .057 & 63091.729 & 5 & 12618.346 & 6.471 & .000 \\
\hline
\end{tabular}

541

542

543

544

Table 4. Results of three models for predicting soil erosion

\begin{tabular}{|c|c|c|c|c|c|c|c|c|}
\hline \multirow{2}{*}{ Methods } & \multirow{2}{*}{ Different modes } & \multirow{2}{*}{ Model } & \multicolumn{3}{|c|}{ Training error } & \multicolumn{3}{|c|}{ Test error rate (test) } \\
\hline & & & MSE & RMSE & $\mathbf{R}$ & MSE & RMSE & $\mathbf{R}$ \\
\hline \multirow{4}{*}{ Grid } & \multirow[b]{2}{*}{5} & Back propagation & 0.003 & 0.03 & 0.66 & 0.03 & 0.03 & 0.66 \\
\hline & & Hybrid & 0.002 & 0.02 & 0.79 & 0.03 & 0.03 & 0.79 \\
\hline & \multirow{2}{*}{10} & Back propagation & 0.003 & 0.04 & 0.67 & 0.04 & 0.05 & 0.68 \\
\hline & & Hybrid & 0.002 & 0.04 & 0.78 & 0.03 & 0.03 & 0.78 \\
\hline \multirow{4}{*}{ Subtractive } & \multirow{2}{*}{0.3} & Back propagation & 0.001 & 0.04 & 0.91 & 0.003 & 0.04 & 0.92 \\
\hline & & Hybrid & 0 & 0.0304 & 0.99 & 0 & 0.0303 & 0.99 \\
\hline & \multirow{2}{*}{0.01} & Back propagation & 0.001 & 0.04 & 0.9 & 0.004 & 0.04 & 0.89 \\
\hline & & Hybrid & 0 & 0.0305 & 0.99 & 0 & 0.0303 & 0.99 \\
\hline \multirow{4}{*}{ FCM } & \multirow[b]{2}{*}{5} & Back propagation & 0.02 & 0.04 & 0.78 & 0.03 & 0.03 & 0.78 \\
\hline & & Hybrid & 0.03 & 0.04 & 0.81 & 0.03 & 0.02 & 0.81 \\
\hline & \multirow{2}{*}{10} & Back propagation & 0.02 & 0.04 & 0.82 & 0.03 & 0.02 & 0.82 \\
\hline & & Hybrid & 0.04 & 0.03 & 0.88 & 0.04 & 0.03 & 0.87 \\
\hline
\end{tabular}

Table 5. The slope coefficient of the studied basins

\begin{tabular}{cccccccc}
\hline Code & $\mathbf{A}_{\mathbf{t}}$ & $\mathbf{A}_{\mathbf{r}}$ & $\mathbf{A}_{\mathbf{f}}$ & $\mathbf{C o d e}$ & $\mathbf{A}_{\mathbf{t}}$ & $\mathbf{A}_{\mathbf{r}}$ & $\mathbf{A}_{\mathbf{f}}$ \\
\hline 1 & 35.78 & 20 & 55.9 & 28 & 1.91 & 0.59 & 30.92 \\
2 & 15.96 & 7.8 & 48.86 & 29 & 2.87 & 0.62 & 21.62 \\
3 & 5.47 & 2.3 & 42.08 & 30 & 1.7 & 0.51 & 29.98 \\
4 & 0.99 & 0.5 & 50.65 & 31 & 0.49 & 0.1 & 20.58 \\
5 & 2.24 & 0.8 & 35.76 & 32 & 1.11 & 0.44 & 39.53 \\
6 & 3.11 & 1.3 & 41.77 & 33 & 0.47 & 0.21 & 45.02 \\
7 & 7.84 & 4.4 & 56.11 & 34 & 0.46 & 0.11 & 23.94 \\
8 & 3.74 & 2.1 & 56.19 & 35 & 26.69 & 10 & 37.47 \\
9 & 5.37 & 3.37 & 62.75 & 36 & 15.48 & 3.6 & 23.26 \\
10 & 6.67 & 3.16 & 47.36 & 37 & 38.76 & 7 & 18.06 \\
11 & 33.84 & 2.2 & 6.5 & 38 & 33.26 & 15 & 45.09 \\
12 & 32.06 & 24.8 & 77.35 & 39 & 41.24 & 10 & 24.25
\end{tabular}




$\begin{array}{lccccccc}13 & 17.35 & 7 & 40.35 & 40 & 49.95 & 24 & 48.05 \\ 14 & 12.56 & 7.4 & 58.91 & 41 & 62.52 & 25 & 39.99 \\ 15 & 6.75 & 3.7 & 54.85 & 42 & 17.82 & 9.1 & 51.07 \\ 16 & 6.71 & 3.2 & 47.72 & 43 & 5.24 & 2.9 & 55.38 \\ 17 & 8.38 & 3.6 & 42.98 & 44 & 10.63 & 3 & 28.22 \\ 18 & 4.62 & 1.5 & 32.45 & 45 & 6.47 & 2.9 & 44.8 \\ 19 & 3.68 & 1.7 & 46.21 & 46 & 5.5 & 2.5 & 45.49 \\ 20 & 3.47 & 1.5 & 43.17 & 47 & 12.66 & 5 & 39.5 \\ 21 & 1.94 & 0.55 & 28.35 & 48 & 6.3 & 2.6 & 41.24 \\ 22 & 1.33 & 0.68 & 51.16 & 49 & 6.6 & 2.3 & 34.86 \\ 23 & 1.24 & 0.47 & 38.03 & 50 & 11.58 & 3.3 & 28.5 \\ 24 & 0.92 & 0.33 & 36 & 51 & 14.49 & 7 & 48.31 \\ 25 & 3.79 & 1.2 & 31.68 & 52 & 11.24 & 5.7 & 50.71 \\ 26 & 3.72 & 1 & 26.9 & 53 & 10.21 & 7 & 68.56 \\ 27 & 1.03 & 0.33 & 32.01 & 54 & 8.51 & 4.2 & 49.35\end{array}$



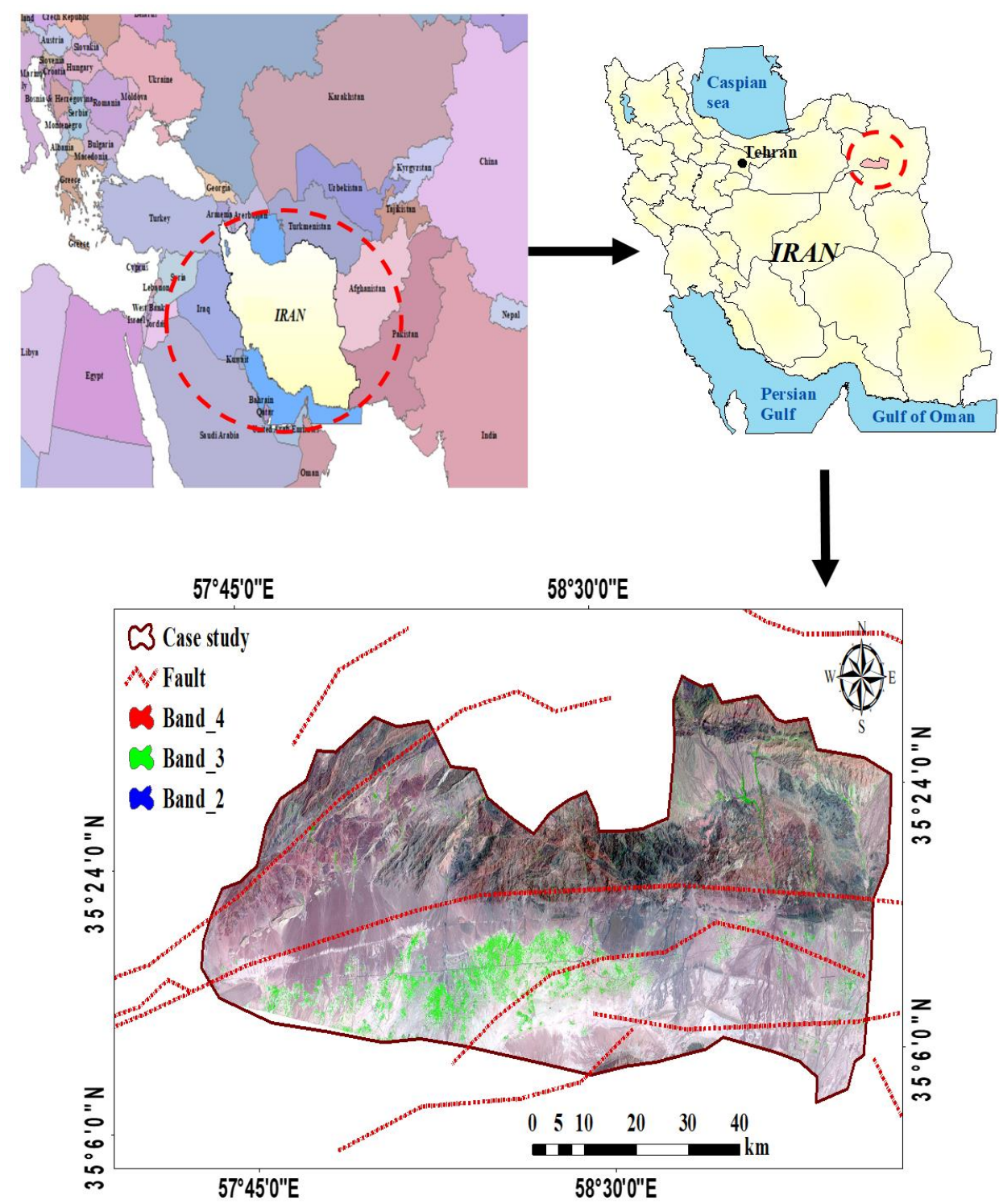

Fig. 1. Location of the study area 

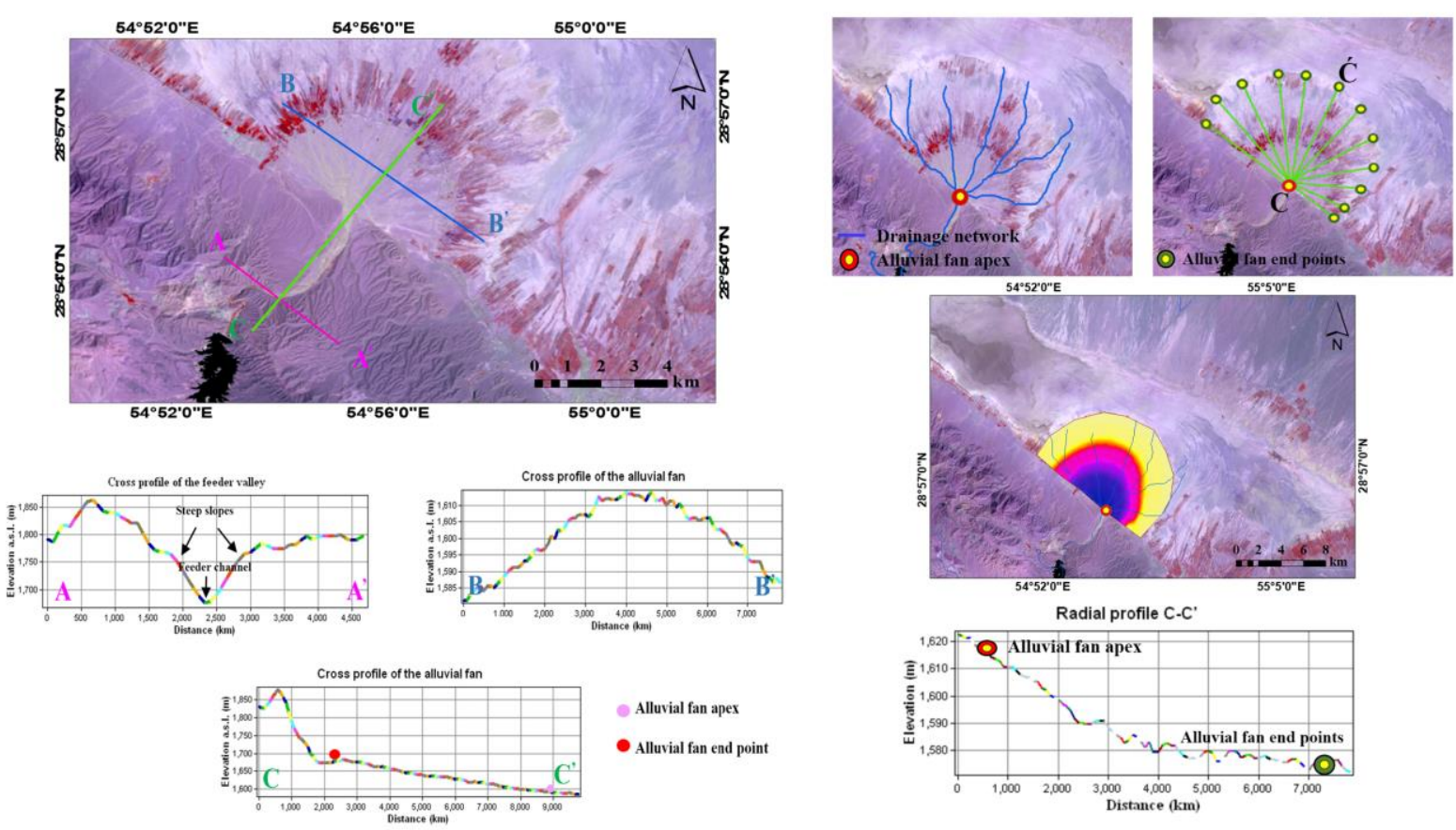

- Alluvial fan apex

- Alluvial fan end point

(a)

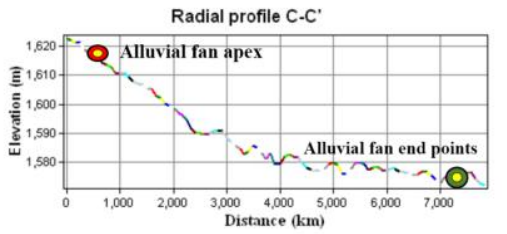

(b)

Fig. 2. (a): Morphological status of a large alluvial fan (a) the alluvial fan from satellite images (b) topographic characteristics of AA', BB', CC' profiles, (b): The steps to extract the alluvial fan with the determination of alluvial fan endpoints; and (C) interpolation of the semi-conical surface.

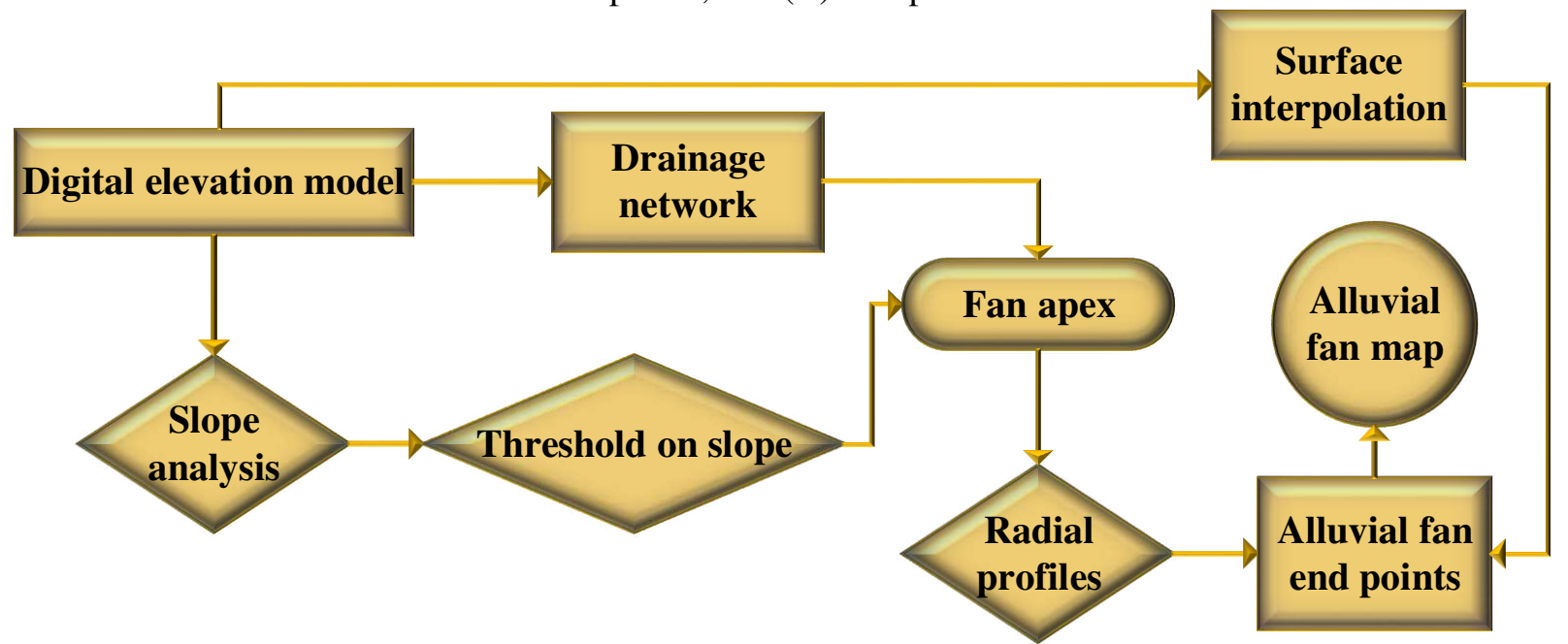

Fig. 3. Flowchart of alluvial fan extraction from DEM. 


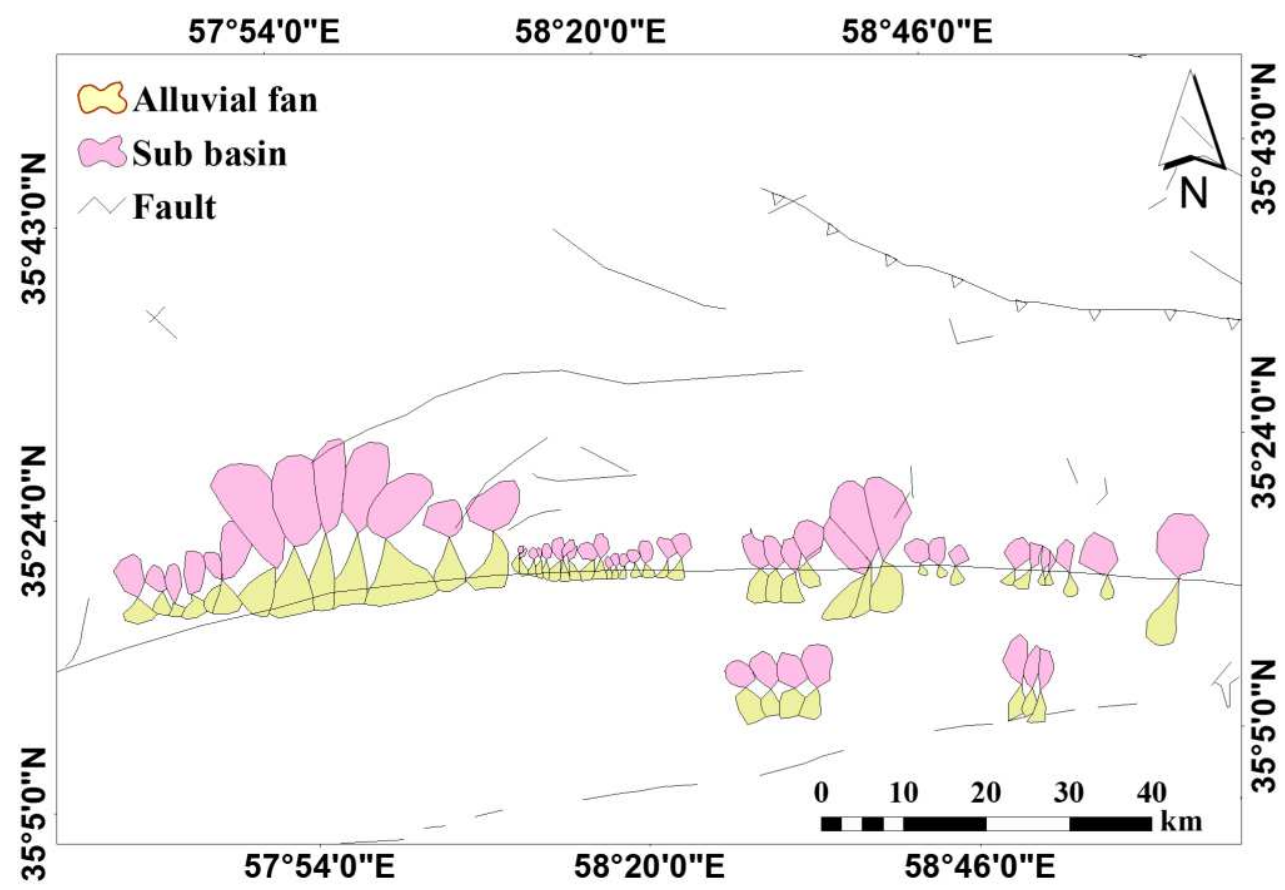

559

Fig. 4. Position of alluvial fans in the study area

560

561

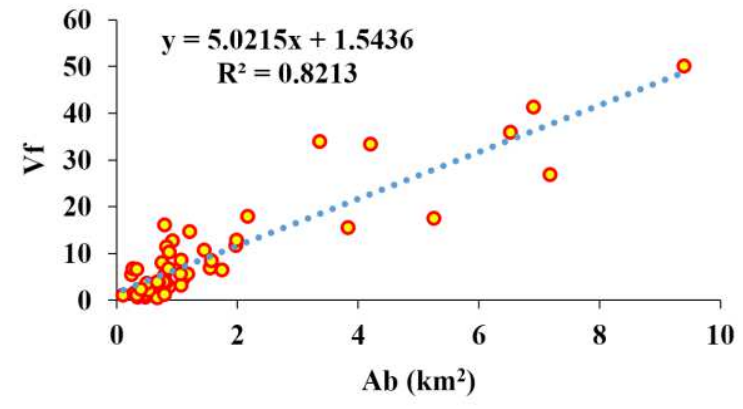

Fig. 5. Relationship between $A_{f}, A_{b}, V_{f}$ 


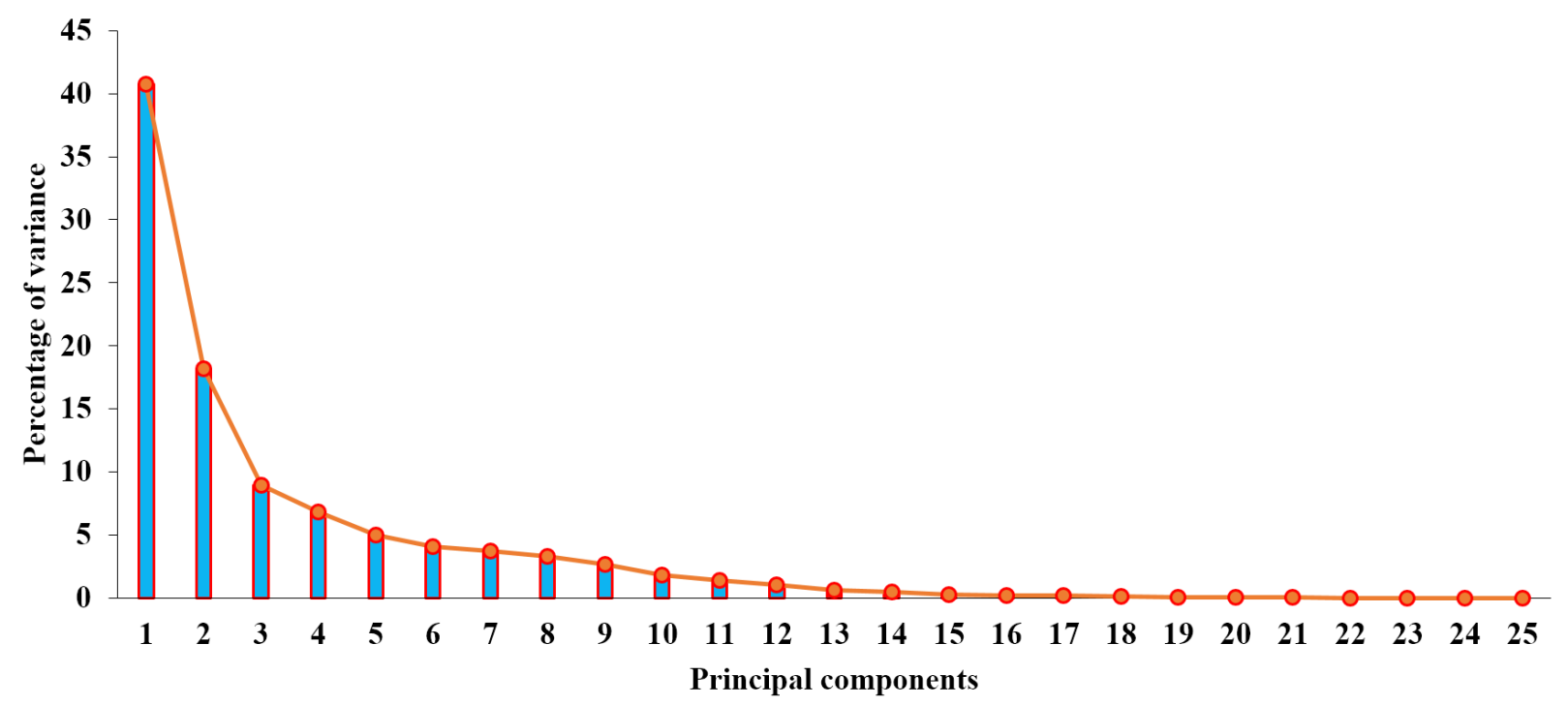

563
564

565

566

567

568

Fig. 6. Percentage of variance expressed by the first 14 principal components for erosion

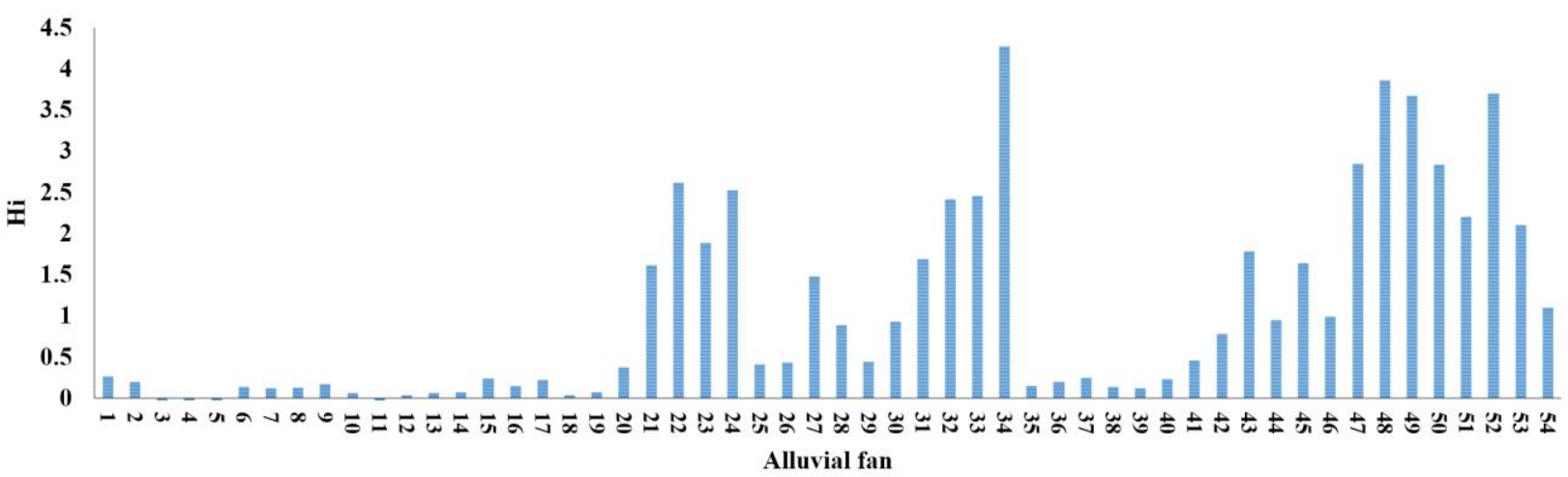

Fig. 7. Altimetry integral values for the sub-basins

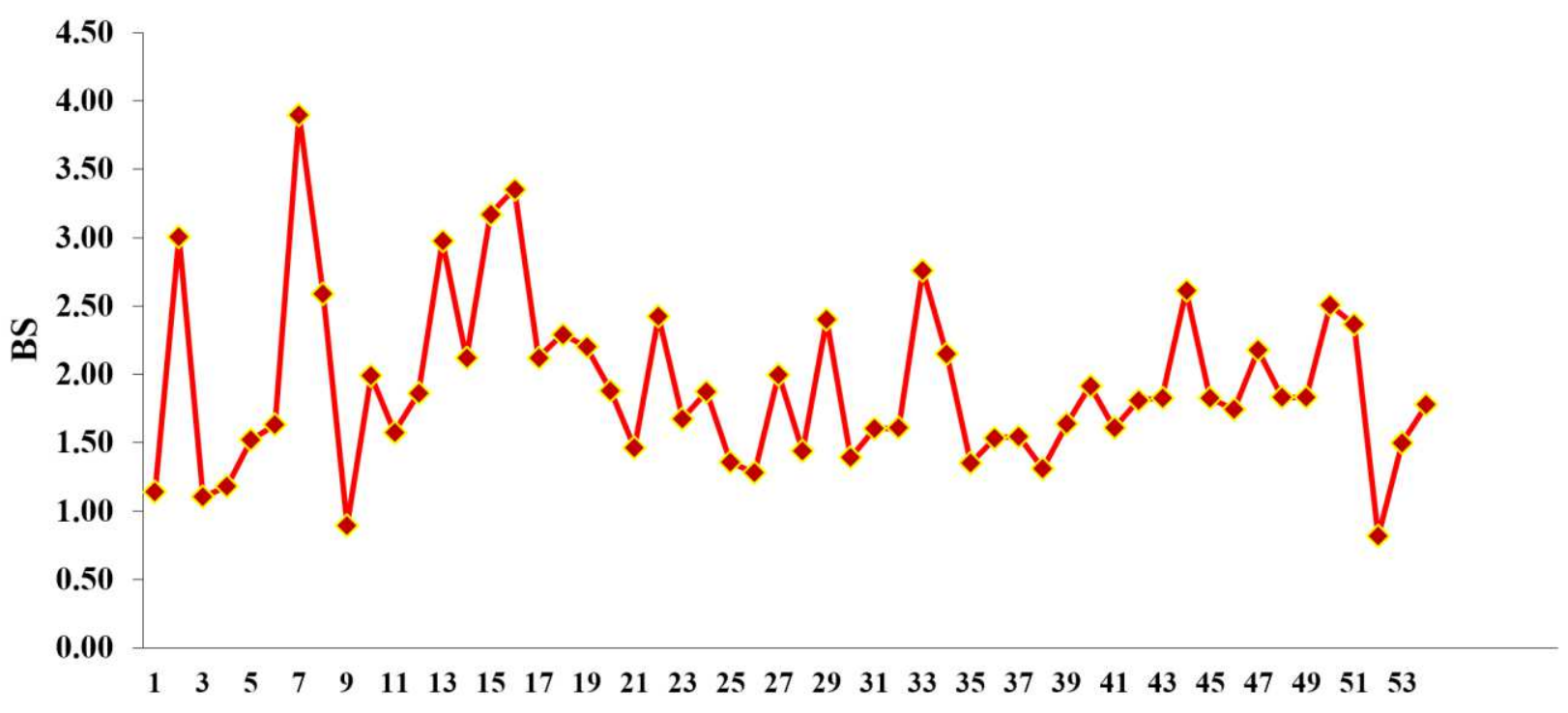

Alluvial fan

Fig. 8. BS values for each of the sub-basins 


\section{Supplementary Files}

This is a list of supplementary files associated with this preprint. Click to download.

- Supplementary2.docx 